(C) Є.С. Сірчак, В.І. Грига, А.В. Стегура, 2020

УДК 616.36-003.826:616.379-008.64]-073

\title{
Неінвазивні методи діагностики ураження печінки у хворих на неалкогольну жирову хворобу печінки та цукровий діабет 2 типу
}

\author{
Є.С. Сірчак, В.I. Грига, А.В. Стегура
}

ДВНЗ «Ужсгородський начіональний університет», медичний факультет, кафедра пропедевтики внутрішніх хвороб, Ужгород

\section{Реферат}

Вступ. Активно ведеться пошук нових неінвазивних високоінформативних методів дослідження щодо визначення стадії ураження, а також функціонального стану печінки, особливо у хворих з поєднаною патологією.

Мета дослідження - оцінити ефективність використання різних неінвазивних методів діагностики для визначення стадії ураження печінки у хворих на неалкогольну жирову хворобу печінки (НАЖХП) та цукровий діабет (ЦД) 2 типу.

Матеріали та методи. Обстежено 64 хворих на НАЖХП та ЦД 2 типу. Хворим проведено загальноклінічні методи обстеження. Ступінь ураження печінки розраховано з використанням сурогатних маркерів фіброзу за допомогою онлайн-калькуляторів: NAFLD fibrosis score (NFS), Fibrosis 4 calculator (FIB-4), фібротест, а також комерційного тесту ФіброМакс. Стадію ураження печінки також визначали за допомогою еластометрії печінки та проводили $\mathrm{C}^{13}$-метацетиновий дихальний тест $\left(\mathrm{C}^{13}-\mathrm{MДT}\right)$.

Результати досліджень та їх обговорення. Результати NFS та FIB-4 дали змогу встановити лише факт наявності фіброзу печінки із високою ймовірністю, тоді як Фібротест дав змогу встановити F2 стадію фіброзу за METAVIR. Результати комерційного тесту ФіброМакс також вказують на наявність стеатогепатиту в обстеже-

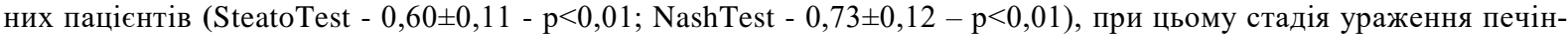

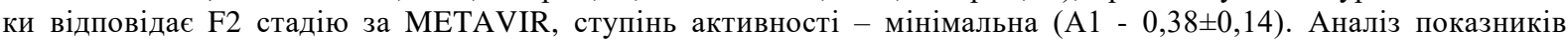

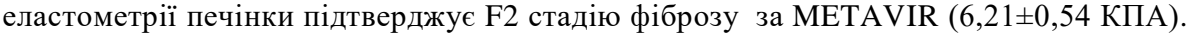

Висновки. У хворих на НАЖХП та ЦД 2 типу використання неінвазивних методів, таких як еластометрія печінки, онлайн фібротест на основі сурогатних маркерів фіброзу печінки та комерційний тест ФіброМакс $\epsilon$ ефективними та інформативними методами для визначення стадії фіброзу у даних пацієнтів.

Ключові слова: неалкогольна жирова хвороба печінки, цукровий діабет 2 типу, діагностика

Non-invasive diagnostic of liver damage in patients with non-alcoholic fatty liver disease and diabetes mellitus type 2

Ye.S. Sirchak, V.I. Hryha, A.V. Stehura

SHEI "Uzhhorod National University", faculty of medicine, Department of propaedeutics of internal diseases, Uzhhorod

Abstract
Introduction: Science is actively searching for new non-invasive and high-informative methods, that can help to reveal the stage of liver damage and also its functional state, especially in patients with combined pathology.

The aim of the research is: to assess the effectiveness of different non-invasive diagnostic methods for revealing the stage of liver damage in patients with non-alcoholic fatty liver disease (NAFLD) and diabetes mellitus (DM) type 2.

Materials and methods: General clinical examination was performed to 64 patients with NAFLD and DM type 2. The extent of liver damage was figured out with the help of surrogate markers of liver fibrosis and online calculator: NAFLD fibrosis score (NFS), Fibrosis 4 calculator (FIB-4), fibrotest and commercial test «FibroMax». Liver damage was also measured with elastometry and metacetin 13C-breath test.

The results of the research: NFS та FIB-4 only showed us the presence of liver fibrosis. At the same time, fibrotest revealed F2 stage of liver fibrosis (according to METAVIR). The results of FibroMax showed us also the presence of steatohepatitis in examined patients (SteatoTest $-0.60 \pm 0.11-\mathrm{p}<0.01$; NashTest $-0.73 \pm 0.12-$ $\mathrm{p}<0.01$ ). The stage of liver damage was appropriate to F2 stage (according to METAVIR), level of activity was minimal (A1 - 0.38 \pm 0.14$)$. The results of elastometry confirmed F2 stage of liver fibrosis according to METAVIR $(6.21 \pm 0.54 \mathrm{kPa})$.

Conclusions: Non-invasive diagnostic methods such as elastometry, online fibrotest based on surrogate markers of liver fibrosis and commercial test FibroMax are effective and informative for revealing the stage of fibrosis in current patients.

Key words: non-alcoholic fatty liver disease, type 2 diabetes mellitus, diagnostic.

Вступ. В останні роки відзначається зростання поширеності неалкогольної жирової хвороби печінки (НАЖХП) паралельно зі збільшенням частоти розвитку ожиріння та цукрового діабету (ЦД) 2 типу. Неалкогольна жирова хвороба печінки займає провідну роль серед інших етіологічних форм хронічних уражень печінки і в даний час іiі розглядають як одну 3 основних причин розвитку криптогенного цирозу печінки. У західних країнах НАЖХП діагностують у 17-46\% дорослого населення і досягає 90\% у популяції пацієнтів $з$ ожирінням [1] 
Неалкогольна жирова хвороба печінки включає дві форми, які розрізняються за морфологічними ознаками i життєвим прогнозом, а саме неалкогольний жировий гепатоз (НАЖГ) та неалкогольний стеатогепатит (НАСГ), що охоплює широкий спектр важких захворювань, таких як фіброз, цироз печінки та гепатоцелюлярна карцинома [1, 2, 3, 4].

На сьогодні «золотим стандартом» діагностики хронічних дифузних уражень печінки, в тому числі НАЖХП, є біопсія печінки, з подальшим морфологічним дослідженням отриманого матеріалу. При цьому, існує безліч протипоказань щодо іiі проведення, що обмежує широке ії використання в клінічній практиці. Активно ведеться пошук нових неінвазивних високоінформативних методів дослідження щодо визначення стадії ураження, а також функціонального стану печінки, особливо у хворих з поєднаною патологією.

Мета дослідження - оцінити ефективність використання різних неінвазивних методів діагностики для визначення стадії ураження печінки у хворих на НАЖХП та ЦД 2 типу.

Наукове дослідження є фрагметном держбюджетної теми кафедри хірургічних хвороб та кафедри пропедевтики внутрішніх хвороб медичного факультету ДВНЗ «УжНУ» № 851 «Механізми формування ускладнень при захворюваннях печінки та підшлункової залози, методи їх лікування та профілактики», номер державної реєстрації: 0115U001103), а також наукової теми кафедри пропедевтики внутрішніх хвороб «Поліморбідна патологія при захворюваннях органів травлення, особливості патогенезу, можливості корекції (номер державної реєстрації 0118U004365).

Матеріали та методи. На клінічній базі кафедри пропедевтики внутрішніх хвороб медичного факультету ДВНЗ «УжНУ» (гастроентерологічне та ендокринологічне відділення ЗОКЛ ім. А. Новака) за 2016-2021 рр. обстежено 64 хворих на НАЖХП та ЦД 2 типу. Середній вік становив $48,9 \pm 5,4$ року. Серед них чоловіків було 39 (60,9\%), жінок $16(39,1 \%)$.

Контрольну групу склало 20 практично здорових осіб (чоловіків було $12(60,0 \%)$, жінок -8 (40,0\%). Середній вік складав 47,6 $\pm 5,8$ року.

Усі дослідження були виконані за згодою пацієнтів (від усіх хворих було отримано письмову згоду щодо проведення відповідних діагностичнолікувальних заходів), а методика їх проведення відповідала Гельсінській декларації з прав людини 1975 р. та іiі перегляду 1983 р., Конвенції Ради Європи про права людини і біомедицину та законодавства України.

Усі обстежені пацієнти підлягали дослідженню за загальноклінічними, антропометричними, інструментальними та лабораторними методами.
Для верифікації діагнозу звертали увагу на характер скарг, анамнез захворювання (виключення зловживання алкоголем). При антропометричному дослідженні визначали зріст, вагу, обвід талії, а також розраховували індекс маси тіла (IMT). Усім хворим виконано ультразвукове дослідження органів черевної порожнини за загальноприйнятою методикою. У сироватці крові проведено стандартні загальні та біохімічні дослідження.

Усім хворим виконано ультразвукове дослідження органів черевної порожнини за загальноприйнятою методикою. В сироватці крові проведено стандартні загальні та біохімічні дослідження для визначення функціонального стану печінки (аланінамінотрансферази (АЛТ), аспартатамінотрансферази (АСТ), загального білірубіну (ЗБ), лужної фосфатази (ЛФ) гамаглутамілтрансфераза (ГГТ)), показників ліпідного обміну (загальний холестерин (3X), тригліцериди (ТГ), ліпропротеїни високої щільності (ЛПВЩ), ліпопротеїни низької щільності (ЛПНЩ), ліпопротеїни дуже низької щільності (ЛПДНЩ), розраховували індекс атерогенності), вуглеводного обміну (глюкози, інсуліну, глікозильованого гемоглобіну (НbA1c), розраховували індекс НОМА).

Діагноз НАЖХП встановили згідно 3 критеріями уніфікованого клінічного протоколу (наказ MO3 України від 06.11.2014 р. № 826) та клінічними рекомендаціями EASL-EASD-EASO щодо діагностики та лікування НАЖХП. Ступінь ураження печінки розраховано з використанням сурогатних маркерів фіброзу за допомогою онлайнкалькуляторів:

1. NAFLD fibrosis score (NFS) - враховуючи вік хворих (роки), показник індексу маси тіла $\left(\kappa г / \mathrm{M}^{2}\right)$, наявність порушення толерантності до глюкози чи цукрового діабету, рівень АЛТ (U/L), ACT (U/L), альбміну (г/л) та кількість тромбоцитів (х 109/л).

При цьому показник відповідає: <-1,455 - предиктор відсутності значного фіброзу (F0-F2 фіброз); $\leq-1,455$ до $\leq 0,675$ : невизначений бал; >0,675: предиктор наявності значного фіброзу (фіброз F3F4).

2. Fibrosis 4 calculator (FIB-4) - у формулі враховується вік пацієнта (роки), рівень АЛТ (U/L), ACT (U/L) та кількість тромбоцитів (х 10\%/л).

При цьому значення менше 1,45 - вірогідність наявності фіброзу мала (близько 90\%); значення більше 3,25 - вірогідність наявності фіброзу велика (близько 90\%).

3. Фібротест - враховується вік (роки), стать хворого, рівень $\gamma$-глутамілтрансферази (Од/л), загального білірубіну (мкмоль/л), аполіпопротеїну (г/л), гаптоглобіну (г/л), $\alpha 2$-макроглобуліну (г/л). Інтерпретація результатів фібротесту наведена у таблиці 1. 
Інтерпретація результатів фібротесту

Таблиця 1

\begin{tabular}{|c|c|c|c|}
\hline FibroTest & METAVIR (Стадія фіброзу) & Knodell (Cтадія фіброзу) & Ishak (Cтадія фіброзу) \\
\hline $0,75-1,00$ & F4 & F4 & F6 \\
\hline $0,73-0,74$ & F3-F4 & F3-F4 & F5 \\
\hline $0,59-0,72$ & F3 & F3 & F4 \\
\hline $0,49-0,58$ & F2 & F1-F3 & F3 \\
\hline $0,32-0,48$ & F1-F2 & F1-F3 & F2-F3 \\
\hline $0,28-0,31$ & F1 & F1 & F2 \\
\hline $0,22-0,27$ & F0-F1 & F0-F1 & F1 \\
\hline $0,00-0,21$ & F0 & F0 & F1 \\
\hline
\end{tabular}

Для більш точного визначення ступеня ураження та активності патологічного процесу в печінці хворим визначався ліцензований тест ФіброМакс, що включає: ФіброТест (FibroTest) - для кількісної оцінки фіброзу; СтеатоТест (SteatoTest) - для кількісної оцінки стеатоза; АктіТест (ActiTest) - для кількісної оцінки некрозозапальної активності в печінці; НешТест (NashTest) - для діагностики неалкогольного стеатогепатиту; ЕшTест (AshTest) - для діагностики алкогольного стеатогепатиту.

Усім хворим також для визначення ступеня ураження печінки проводили $\mathrm{C}^{13}$-метацетиновий дихальний тест ( $\mathrm{C}^{13}$-МДТ). Принцип методу полягає в тому, що $\mathrm{C}^{13}$-метацетин у печінці підлягає ферментативному деметилюванню і декарбоксилюванню при взаємодії мікросомальних ферментів цитохрома Р450. Кінцевим продуктом метаболізму $\mathrm{C}^{13}$-метацетину $€{ }^{13} \mathrm{CO}_{2}$, інтенсивність елімінації якого через легені й дозволяє робити висновок про функціональний стан мікросомальних ензимних систем гепатоцитів. Під час проведення тесту отримали 10 дихальних проб: вихідну, до прийому тестового сніданку (75 мг $\mathrm{C}^{13}$-метацину, який розчиняли у 200 мл фруктового чаю без цукру, температура чаю складала $35-40^{\circ} \mathrm{C}$ ), та ще 6 проб протягом першої години (по одній кожні 10 хвилин) і 3 проби - впродовж другої години (по одній кожні 20 хвилин). Дихальні проби аналізували на інфрачервоному спектроскопі IRIS (фірми IZINTA, Угорщина). Результати, отримані при аналізі, представлені в графічній формі. Висновки про функціональний стан печінки отримали на основі співвідношення кривої сумарної концентрації ${ }^{13} \mathrm{CO}_{2}$ протягом 120 хвилин дослідження 3 кривими, одержаними при дослідженні здорових волонтерів, які відображають верхню i нижню межі норми до результатів обстежених пацієнтів.

У пацієнтів, які страждають на захворювання, що супроводжуються печінковою недостатністю, сумарна концентрація ${ }^{13} \mathrm{CO}_{2} є$ суттєво зниженою протягом усього дослідження. Оцінка результатів за описаною методикою наведена у таблиці 2.

Оцінка результатів ${ }^{13} \mathrm{C}$-метацетинового дихального тесту

Таблиця 2

\begin{tabular}{|c|c|l|}
\hline $\begin{array}{c}\text { Сумарна концентрація } \\
{ }^{13} \mathrm{CO}_{2} \text { до 120 хвилини, \% }\end{array}$ & $\mathrm{MV}_{\max } 40 / \mathrm{CUM} 40$ & \multicolumn{1}{|c|}{ Інтерпретація результатів } \\
\hline $20-35 \%$ & $0,80-1,20$ & $\begin{array}{l}\text { нормальна функція печінки, маса функціонуючих } \\
\text { гепатоцитів (МФГ) 100\% }\end{array}$ \\
\hline $10-20 \%$ & $0,25-0,50$ & $\begin{array}{l}\text { помірне 3ниження функції печінки, } \\
\text { МФГ 50-100\% }\end{array}$ \\
\hline $2-10 \%$ & $0,15-0,25$ & $\begin{array}{l}\text { виражене 3ниження функції печінки, } \\
\text { МФГ 20-50\% }\end{array}$ \\
\hline$<2 \%$ & $0-0,15$ & $\begin{array}{l}\text { важке 3ниження функції печінки, } \\
\text { МФГ <20\% }\end{array}$ \\
\hline
\end{tabular}

Також обстеженим пацієнтам проведено еластометрію печінки. Дослідження виконувалось у горизонтальному положенні пацієнта натще апаратом AcusonS 2000 (Siemens) 3 конвексним датчиком. Для визначення ступеня фіброзу печінки був використа- ний УЗ-режим еластографії. Проводили 5 повних вимірювань, медіана їх використовувалась як остаточний показник жорсткості печінки. Ступінь фіброзу печінки визначався в коефіцієнті жорсткості (КПА) за шкалою METAVIR (табл. 3). 
Оцінка результатів еластометрії печінки

\begin{tabular}{|l|l|c|c|c|}
\hline \multirow{4}{*}{} & \multicolumn{3}{|c|}{ Показник } \\
\cline { 2 - 5 } & \multicolumn{2}{|c|}{$\begin{array}{c}\text { Стадії фіброзу } \\
\text { за шкалою METAVIR }\end{array}$} & м/с \\
\cline { 2 - 5 } & Норма & F0 & $2,0-4,5$ & $0,81-1,23$ \\
\hline \multirow{2}{*}{$\begin{array}{l}\text { Стадіï } \\
\text { фіброзу }\end{array}$} & Незначна & F1 & $4,5-5,7$ & $1,23-1,37$ \\
\cline { 2 - 5 } & Помірна & F2 & $5,7-8,8$ & $1,37-1,68$ \\
\cline { 2 - 5 } & & F3 & $8,8-12,0$ & $1,68-2,0$ \\
\cline { 2 - 5 } & Значна & F4 & $2,0-2,64$ \\
\cline { 2 - 5 } & Виражена & F4 & 2,0 & $2,64->$ \\
\hline
\end{tabular}

Діагноз ЦД 2 типу встановлено згідно з рекомендаціями IDF (2005 р.), а також із урахуванням критеріїв уніфікованого клінічного протоколу (наказ МО3 України від 21.12.2012 № 1118). Ступінь важкості ЦД 2 типу оцінювали за рівнем HbA1c (норма - до 6,0 \%) [5, 6].

Аналіз і обробка результатів обстеження хворих здійснювалася за допомогою комп'ютерної програми STATISTICA 10.0 (фірми StatSoft Inc,
USA) 3 використанням параметричних та непараметричних методів оцінки отриманих результатів.

Результати досліджень та їх обговорення. У всіх пацієнтів, які знаходились під нашим спостереженням, за результатами лабораторноінструментальних методів дослідження діагностовано ЦД 2 типу середнього ступеня важкості, а також встановлено зміни, характерні для стеатогепатиту.

Таблиця 4

Зміна показників функціонального стану печінки в обстежених хворих на НАЖХП та ЦД 2 типу

\begin{tabular}{|c|c|c|}
\hline \multirow{2}{*}{ Показник } & \multicolumn{2}{|c|}{ Обстежені } \\
\cline { 2 - 3 } & $\begin{array}{c}\text { Контрольна група } \\
(\mathrm{n}=20)\end{array}$ & $\begin{array}{c}\text { Хворі на НАЖХП та ЦД 2 типу } \\
(\mathrm{n}=64)\end{array}$ \\
\hline АЛТ, ОД/л & $22,6 \pm 1,5$ & $139,6 \pm 4,7^{* *}$ \\
\hline АСТ, ОД/л & $24,3 \pm 2,5$ & $62,1 \pm 3,7^{*}$ \\
\hline ЗБ, ммоль/л & $12,7 \pm 0,9$ & $27,7 \pm 1,8^{*}$ \\
\hline ЛФ, ммоль/л & $72,6 \pm 3,4$ & $125,7 \pm 4,0^{*}$ \\
\hline ГГТ, ОД/л & $37,2 \pm 4,1$ & $68,6 \pm 3,1^{*}$ \\
\hline
\end{tabular}

Примітка: між показниками контрольної групи та обстеженими хворими різниця статистично достовірна: * $-\mathrm{p}<0,05$; $* *-p<0,01$.

Встановлено достовірне підвищення рівня АЛТ у $(6,2$ разу - p $<0,01)$ та ACT $(2,6$ разу - p<0,05), a

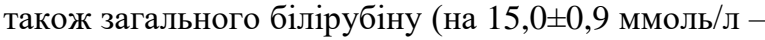
$\mathrm{p}<0,05)$, лужної фосфатази $(1,7$ разу $-\mathrm{p}<0,05)$ та ГГТ $(1,8$ разу $-\mathrm{p}<0,05)$ у сироватці крові (табл. 4$)$.
Із отриманих даних встановлено, що у всіх хворих на НАЖХП та ЦД 2 типу простежувалося порушення ліпідного профілю. Результати представлені у таблиці 5.

Таблиця 5

Зміна показників ліпідного обміну у сироватці крові в обстежених хворих на НАЖХП та ЦД 2 типу

\begin{tabular}{|c|c|c|}
\hline \multirow{2}{*}{ Показник } & \multicolumn{2}{|c|}{ Обстежені } \\
\cline { 2 - 3 } & $\begin{array}{c}\text { Контрольна група } \\
(\mathrm{n}=20)\end{array}$ & $\begin{array}{c}\text { Хворі на НАЖХП та ЦД 2 типу } \\
(\mathrm{n}=64)\end{array}$ \\
\hline ТГ, ммоль/л & $1,17 \pm 0,09$ & $2,45 \pm 0,21^{*}$ \\
\hline 3Х, ммоль/л & $4,62 \pm 0,78$ & $7,18 \pm 0,45^{*}$ \\
\hline ЛПНЩ, ммоль/л & $1,72 \pm 0,44$ & $3,46 \pm 0,28^{* *}$ \\
\hline ЛПДНЩ, ммоль/л & $0,57 \pm 0,07$ & $1,89 \pm 0,32^{* *}$ \\
\hline ЛПВЩ, ммоль/л & $1,85 \pm 0,07$ & $1,02 \pm 0,09$ \\
\hline КА & $1,53 \pm 0,24$ & $5,89 \pm 0,72^{* *}$ \\
\hline
\end{tabular}

Примітка: між показниками контрольної групи та обстеженими хворими різниця статистично достовірна: * $-\mathrm{p}<0,05$; $* *-p<0,01$. 
Аналіз отриманих даних вказує на збільшення рівня тригліцеридів (у 2,1 разу - $\mathrm{p}<0,05)$, загального холестерину (у 1,6 разу - p $<0,05)$, а також ЛПНЩ (у
2,0 разу - $<<0,01)$ та ЛПДНЩ (у 3,3 разу $-\mathrm{p}<0,01)$, що супроводжувалося зниженням показника ЛПВЩ (до 1,02 $\pm 0,09$ ммоль/л) у сироватці крові.

Таблиця 6

Зміна показників вуглеводного обміну у сироватці крові в обстежених хворих на НАЖХП та ЦД 2 типу

\begin{tabular}{|l|c|c|}
\hline \multirow{2}{*}{\multicolumn{1}{|c|}{ Показник }} & \multicolumn{2}{|c|}{ Обстежені } \\
\cline { 2 - 3 } & $\begin{array}{c}\text { Контрольна група } \\
(\mathrm{n}=20)\end{array}$ & $\begin{array}{c}\text { Хворі на НАЖХП та ЦД 2 типу } \\
(\mathrm{n}=64)\end{array}$ \\
\hline Глюкоза в крові натще, ммоль/л & $4,53 \pm 0,21$ & $9,66 \pm 0,18^{*}$ \\
\hline HbА1с, \% & $4,19 \pm 0,27$ & $8,67 \pm 0,12^{* *}$ \\
\hline Інсулін, Од/л & $8,51 \pm 0,74$ & $22,23 \pm 1,47^{* *}$ \\
\hline С-пептид, нг/мл & $4,05 \pm 0,23$ & $11,08 \pm 0,98^{* *}$ \\
\hline НОМА-IR & $1,61 \pm 0,34$ & $6,14 \pm 0,72^{* *}$ \\
\hline
\end{tabular}

Примітка: між показниками контрольної групи та обстеженими хворими різниця статистично достовірна: * $-\mathrm{p}<0,05$; $* *-\mathrm{p}<0,01$.

У обстежених пацієнтів на фоні збільшеного рівня глюкози виявлено підвищення рівня HbA1c, а також високі показники інсуліну та
C-пептиду у сироватці крові, що супроводжувалось відповідним збільшенням HOMA-IR (табл. 6).

Таблиця 7

Показники лабораторно-інструментальних методів дослідження для визначення ступеня ураження печінки в обстежених хворих на НАЖХП та ЦД 2 типу

\begin{tabular}{|c|c|c|}
\hline \multirow[b]{2}{*}{ Показник } & \multicolumn{2}{|c|}{ Обстежені } \\
\hline & $\begin{array}{c}\text { Контрольна група } \\
(\mathrm{n}=20)\end{array}$ & $\begin{array}{c}\text { Хворі на НАЖХП та ЦД } 2 \text { типу } \\
(\mathrm{n}=64)\end{array}$ \\
\hline \multicolumn{3}{|l|}{ Онлайн фібротести: } \\
\hline$-\quad$ NFS & $-1,25 \pm 0,05$ & $0,378 \pm 0,012 * *$ \\
\hline - $\quad$ FIB-4 & $1,04 \pm 0,05$ & $4,12 \pm 0,07 * *$ \\
\hline Фібротест & $0,18 \pm 0,02$ & $0,52 \pm 0,06^{* *}$ \\
\hline \multicolumn{3}{|l|}{ ФіброМакс: } \\
\hline - $\quad$ FibroTest & $0,13 \pm 0,05$ & $0,38 \pm 0,07 *$ \\
\hline - $\quad$ SteatoTest & $0,17 \pm 0,08$ & $0,60 \pm 0,11 * *$ \\
\hline - $\quad$ ActiTest & $0,11 \pm 0,05$ & $0,38 \pm 0,14^{*}$ \\
\hline - $\quad$ NashTest & $0,18 \pm 0,07$ & $0,73 \pm 0,12 * *$ \\
\hline - $\quad$ AshTest & $0,11 \pm 0,03$ & $0,14 \pm 0,05$ \\
\hline $\mathrm{C}^{13}-\mathrm{MДТ,} \mathrm{\%}$ & $32,11 \pm 4,15$ & $18,04 \pm 2,61 *$ \\
\hline Еластометрія печінки, КПА & $2,83 \pm 0,15$ & $6,21 \pm 0,54 * *$ \\
\hline
\end{tabular}

Примітка: між показниками контрольної групи та обстеженими хворими різниця статистично достовірна: * - p $<0,05$; $* *-\mathrm{p}<0,01$.

Результати проведених досліджень вказують на ураження печінки у обстежених хворих за результатами всіх проведених нами тестів (табл. 7). Слід зазначити, що за допомогою ФіброМакс вдалося виключити алкогольне ураження печінки. Якщо результати NFS та FIB-4 дали змогу встановити лише факт наявності фіброзу печінки із високою ймовірністю, то результати Фібротест (що нами розраховано онлайн) вказують на F2 стадію фібро- зу за METAVIR. Отримані дані за комерційним тестом ФіброМакс також вказують на наявність стеатогепатиту в обстежених пацієнтів (SteatoTest

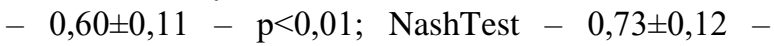
$\mathrm{p}<0,01)$, при цьому ураження печінки відповідає F2 стадії за METAVIR, ступінь активності - мінімальна (A1 - 0,38 $\pm 0,14)$. Аналіз показників еластометрії печінки вказує на F2 стадію фіброзу за METAVIR (6,21 $\pm 0,54$ KПА). 
Зіставлення показників ФіброМакс з іншими результатами лабораторно-інструментальних методів визначення ступеня ураження печінки у хворих на НАЖХП та ЦД 2 типу

\begin{tabular}{|c|c|c|c|c|}
\hline \multirow{2}{*}{ Показник } & \multicolumn{3}{|c|}{ ФіброМакс } \\
\cline { 2 - 5 } & FibroTest & SteatoTest & NashTest & ActiTest \\
\hline Фібротест & $\mathrm{r}=0,94 ; \mathrm{p}<0,01$ & $\mathrm{r}=0,72 ; \mathrm{p}<0,01$ & $\mathrm{r}=0,70 ; \mathrm{p}<0,05$ & $\mathrm{r}=0,90 ; \mathrm{p}<0,01$ \\
\hline $\mathrm{C}^{13}$-МДТ & $\mathrm{r}=0,90 ; \mathrm{p}<0,01$ & - & $-\mathrm{r}=0,76 ; \mathrm{p}<0,01$ \\
\hline $\begin{array}{c}\text { Еластометрія } \\
\text { печінки }\end{array}$ & $\mathrm{r}=0,96 ; \mathrm{p}<0,01$ & $\mathrm{r}=0,84 ; \mathrm{p}<0,01$ & $\mathrm{r}=0,88 ; \mathrm{p}<0,01$ & $\mathrm{r}=0,92 ; \mathrm{p}<0,01$ \\
\hline
\end{tabular}

Проведений кореляційний аналіз дав змогу встановити високу відповідність результатами, отриманими під час проведення еластометрії печінки, та компонентами тесту ФіброМакс (ступеня фіброзу, активністю та підтвердженням факту стеатозу печінки). Між компонентами комерційного тесту ФіброМакс та показниками фібротесту, розрахованими нами онлайн на основі сурогатних маркерів фіброзу печінки, також встановлена сильна кореляційна залежність. Слід зазначити, що проведення $\mathrm{C}^{13}$-МДТ не виправдало його ефективність і інформативність у хворих на НАЖХП та ЦД 2 типу. Дихальний метацетиновий тест дає змогу встановити лише факт ураження печінки, а також дати кількість функціонуючих гепатоцитів, але при цьому не вказує на можливий етіологічний фактор захворювання.

Отже, у хворих на НАЖХП та ЦД 2 типу еластометрія печінки у поєднанні з онлайн фібротестом $\epsilon$ інформативними методами дослідження стадії фіброзу у даних пацієнтів, а ФіброМакс, окрім цього, ще вказує на можливий етіологічний фактор захворювання, а також ступінь активності у печінці.

Встановлено порушення синтетичної функції печінки, що проявляється зниженням рівня загального білка у сироватці крові. Амінокислотний дисбаланс, що виникає при метаболічно індукованих розладах, у даних пацієнтів вимагає подальшого дослідження в даному напрямку для розуміння процесів, що відбуваються в організмі у хворих при НАЖХП та ЦД 2 типу.

Висновки. У хворих на НАЖХП та ЦД 2 типу використання неінвазивних методів, таких як еластометрія печінки, онлайн фібротест на основі сурогатних маркерів фіброзу печінки та комерційний тест ФіброМакс є ефективними та інформативними методами для визначення стадії фіброзу в даних пацієнтів.

Конфлікт інтересів - відсутній.

Інформація про фінансування. Автори не отримували ніяких винагород ні в якій формі від фірмвиробників лікарських препаратів, медичного обладнання та матеріалів, у тому числі конкурентів, здатних вплинути на результати роботи.

Особистий внесок кожного автора у виконання роботи:

Сірчак С.С. - концепція і дизайн дослідження.

Грига В.І. - збір, обробка й аналіз матеріалів, написання тексту.

Стегура А.В. - збір матеріалів, проведення еластометрії печінки.

\section{Список використаної літератури}

1. Semenistaya MCh, Czyanyhao Fan, Velichenko OV et al. Non-alcoholic fatty liver disease: Comparative assessment of approaches to diagnosis and therapy in the Russian Federation and the People's Republic of China. Journal. Gastroenterol. Hepatol. Coloproctol. 2017; 27 (6): 63-70.

2. European Association for the Study of the Liver (EASL), European Association for the Study of Diabetes (EASD) and European Association for the Study of Obesity (EASO) EASL-EASD-EASO Clinical Practice Guidelines for the management of non-alcoholic fatty liver disease. Journal of Hepatology. 2016; 64: 13881402. doi.org/10.1016/j.jhep.2015.11.004.

3. Ivaskin VT Diagnosis and treatment of nonalcoholic fatty liver disease: clinical recommendations. Moskva: MED-press-inform; 2015, 32 p. (in Russian)

4. Fadienko GD, Gridnyev AE Efficiency and safety of ademetionine in the correction of liver function in patients with steatohepatitis. The results of an open comparative post-marketing study. Gastroenterology. $2018 ; 52$ (2): 27-34. (in Russian)

5. Hobzej MK, Guljchij MV, Stepanenko AV et al. Type 2 Diabetes Mellitus. Unified clinical protocol for primary and secondary (specialized) medical care. Kijiv; 2012. 118 p. (in Ukrainian). http://ukrgastro.com.ua/klinichni-protokoli-ta-nastanovi/

6. Hobzej MK, Matyuha LF, Netjazhenko VZ et al. Type 2 Diabetes Mellitus. Adapted clinical guideline based on evidence. Kijiv; 2012. 343 p. (in Ukrainian). http://ukrgastro.com.ua/klinichni-protokoli-ta-nastanovi/

Стаття надійшла до редакції: 1.10.2020 р. 